Terbit online pada laman web jurnal: http://journal.isas.or.id/index.php/JASENS

JOURNAL OF APPLIED SMART ELECTRICAL
NETWORK AND SYSTEMS (JASENS)
ISAS

\title{
Optimasi Battery Charging pada Pendingin Minuman Dengan Sumber Solar Cell Untuk Beban Peltier Menggunakan Buckboost Converter
}

\author{
Hamzah Maulana Azhar ${ }^{1}$ \\ ${ }^{1}$ Teknik Elektronika, Teknik Elektro, Politeknik Negeri Malang \\ ${ }^{1}$ hamzahmaulanaazhar@gmail.com*
}

\begin{abstract}
Currently, many electronic devices use the energy source from the solar cell which is stored in a battery. The battery is a portable, rechargeable power source. Solar energy is very suitable when converted to electrical energy because the amount of sunlight is infinite even though there is a period of time between sunrise and sunset. Converting solar energy to electrical energy requires a solar cell. One method that can be done is using the buck boost converter method with solar cell sources to create a battery charging control system. The Buck Boost Converter method was chosen because it can stabilize the output voltage from the solar cell when the weather is uncertain. If the light intensity of the sunlight is dim, the output voltage of the panel will also be low, then the converter will be in boost mode to increase the voltage level, on the other hand, if the light intensity of the panel output voltage will also be high, the converter will be in buck mode to lower the voltage level. The output voltage of this control system is maintained according to the battery charging voltage standard, which is 14 volts DC.
\end{abstract}

Keywords: solar cell, buck boost converter, battery.

\begin{abstract}
Abstrak
Saat ini banyak perangkat elektronik yang menggunakan sumber energi dari solar cell yang disimpan dalam sebuah battery. Battery merupakan sumber listrik portable yang dapat di isi ulang. Energi matahari sangat cocok jika dikonversi ke energi listrik karena sinar matahari jumlahnya tak terbatas meskipun ada kurun waktunya antara terbit sampai terbenam. Proses konversi energi matahari ke energi listrik membutuhkan suatu solar cell. Salah satu metode yang dapat dilakukan adalah menggunakan metode buck boost converter bersumber solar cell untuk membuat sistem pengendali pengisian battery. Metode Buck Boost Converter dipilih karena dapat menstabilkan tegangan keluaran dari solar cell ketika cuaca tidak menentu. Jika intensitas cahaya matahari redup tegangan keluaran panel juga akan rendah, maka converter akan berada dalam mode boost untuk meningkatkan level tegangan, sebaliknya jika intensitas cahaya terang tegangan keluaran panel juga akan tinggi, maka converter akan berada dalam mode buck untuk menurunkan level tegangan. Tegangan output dari sistem pengendali ini dijaga sesuai standar tegangan pengisian battery yaitu 14 volt DC.
\end{abstract}

Kata kunci: solar cell, buck boost converter, battery.

Diterima Redaksi : 24-05-2021 | Selesai Revisi : 21-06-2021 | Diterbitkan Online : 30-06-2021

\section{Pendahuluan}

Selama ini baru ada alat charging battery yang hanya berfungsi sebagai regulator tegangan solar cell saja. Penelitian sebelumnya telah dilakukan terkait battery charging bersumber solar cell yang dilakukan oleh Dani $\mathrm{S}$ [1] dan Aulia Rizki[2]. Pada penelitian tersebut DC DC Converter menggunakan boost. Pada penelitian tersebut DC DC Converter menggunakan boost converter. Namun dengan metode boost converter hanya mengandalkan tegangan lebih rendah untuk di regulasi ke level lebih tinggi. Hal itu tentunya akan sangat merugikan karena pada kondisi cuaca yang tidak menentu menyebabkan output dari solar cell tidak akan mencapai standar tegangan pengisian battery. Untuk itu perlu adanya suatu metode yang dapat mengefektifkan tegangan output solar cell karena intensitas cahaya matahari yang berubah - ubah.

PLTS adalah sebuah pembangkit listrik yang memanfaatkan sinar matahari berupa radiasi sinar foton matahari yang kemudian akan dikonversikan menjadi energi listrik melalui sel surya (photovoltaic). Sel surya (photovoltaic) sendiri merupakan suatu lapisan tipis yang terbuat dari bahan semikonduktor silikon (Si) murni dan bahan semikonduktor lainnya. Sinar matahari yang dimanfaatkan oleh PLTS ini akan memproduksi listrik DC yang dapat dikonversi menjadi listrik AC apabila dibutuhkan. Dan PLTS ini akan tetap menghasilkan listrik meskipun cuaca mendung selama masih terdapat cahaya[3]. Modul photovoltaic dengan kapasitas 50 wattpeak. Radiasi matahari rata-rata harian yang didapat sebesar 4,5 kWh/m2 yang akan 
menghasilkan energi listrik kurang lebih 125 hingga 130 watt-jam[4].

Melalui survey literatur, melaporkan bahwa faktor efisiensi merupakan tantangan terbesar dalam pemanfaatan energi matahari menjadi energi listrik[5]. Sistem penjejak matahari sesuai dengan arah datangnya cahaya matahari diperoleh peningkatan energi matahari sebesar $30 \%$ yang berhasil diubah menjadi energi listrik[6]. Efisiensi energi matahari yang diserap untuk dikonversikan menjadi energi listrik sebesar $90 \%[7][8]$. Pengendali elektromekanik yang berfungsi menjejak cahaya matahari diperoleh energi matahari yang maksimum dan berdasarkan hasil penelitiannya diperoleh energi matahari hingga $60 \%$ [9]. Karakteristik listrik dari setiap modul surya tidak identik, perbedaan dalam orientasi dan arah datang sinar matahari ke setiap modul surya, dan sebagainya[10]. Kondisi ketidaksesuaian antar modul surya menyebabkan daya hilang (losses) hampir 25\% dalam menghasilkan energi listriknya[11]. Untuk menanganinya, rangkaian elektronika daya yang disebut DC-DC Converter yang sesuai harus dirancang agar dapat mengkompensasi nilai tersebut.

\section{Metode Penelitian}

\subsection{Blok Diagram}

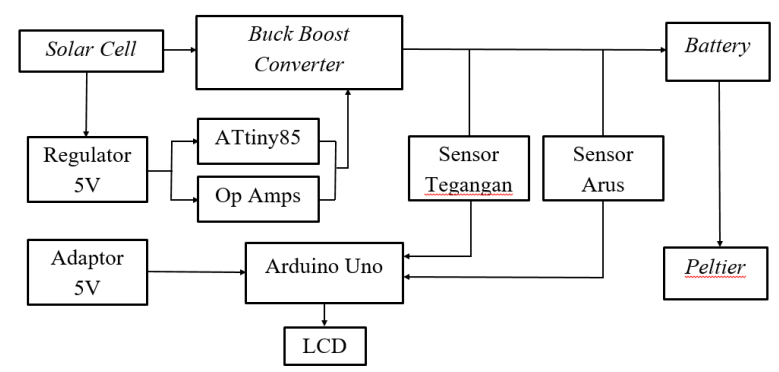

Gambar 1. Blok Diagram Sistem

Gambar diatas menunujukkan blok diagram sistem yang terdiri dari solar cell, buck boost Converter, ATtiny85, op amps, sensor tegangan, sensor arus, arduino, battery, regulator regangan, $L C D$, dan peltier sebagai beban akhir. Pertama adalah cahaya matahari yang dikonversi oleh solar cell menjadi tegangan dan arus. Setelah itu, tegangan dan arus masuk ke regulator LM7805, lalu tegangan diturunkan menjadi $5 \mathrm{~V}$ untuk mensuplai ATtiny85 dan MCP602 yang berfungsi sebagai pendeteksi tegangan keluaran solar cell. Tegangan tersebut masuk ke pin PB2 (gambarnya bisa dilihat di perancangan ATtiny85). Lalu output MCP602 yang berupa tegangan menjadi input pin PB3. Mikrokontroler membaca input pada PB2 dan PB3 lalu membangkitkan sinyal PWM sesuai dengan yang telah di set. Pada pin PB1 mengeluarkan sinyal PWM untuk switching mosfet pada kaki gate. Sedangkan pada kaki drain disambungkan ke lilitan untuk mengatur besar kecilnya tegangan output. Apabila mosfet on, maka kapasitor akan mengosongkan tegangan. Lalu tegangan tersebut melewati dioda. Sebaliknya apabila mosfet off, maka kapasitor akan mengisi. Keluaran dari buck boost converter digunakan untuk pengisian battery. Tegangan dan arus yang masuk ke battery akan disensor oleh sensor tegangan dan sensor arus kemudian diolah oleh Arduino untuk ditampilan pada LCD. Peltier sebagai beban akhir mendapatkan daya dari battery untuk mendinginkan minuman.

\subsection{Perancangan Modul Sensor Tegangan}

Dalam pembacaan tegangan panel surya oleh ADC mikrokontroller diperlukan sebuah sensor yang dapat menurunkan tegangan menjadi tegangan yang dibutuhkan oleh ADC mikrokontroller, namun tetap dapat mewakili nilai tegangan asli. Oleh karena itu, digunakan prinsip dasar rangkaian listrik voltage divider atau pembagi tegangan untuk menurunkan tegangan pada panel surya yang kemudian masuk ke ADC mikrokontroller.

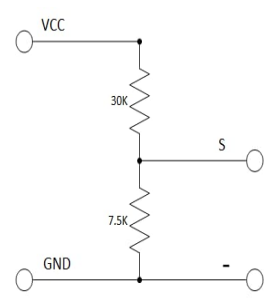

Gambar 2. Rangkaian Dasar Modul Sensor Tegangan

Perhitungan dari nilai resistor yang digunakan pada rangkaian modul sensor tegangan ditunjukkan pada persamaan dibawah ini:

Vout $=\frac{R 2}{R 1+R 2} x$ Vin

$5=\frac{R 2}{R 1+R 2} \times 25$

$5 R 1+5 R 2=25 R 2$

$5 R 1=20 R 2$

Jika $R 1=30 k$,

$R 2=\frac{5 \times 30 k}{20}$

$R 2=7 \mathrm{k} 5$

Selanjutnya akan membahas tentang sensor tegangan dengan Op Amps, Op Amps yang digunakan adalah MCP602 yang berfungsi sebagai pendeteksi tegangan keluaran solar cell. Keluaran dari op amps terhubung ke mikrokontroler sebagai masukan yang sudah di filter.

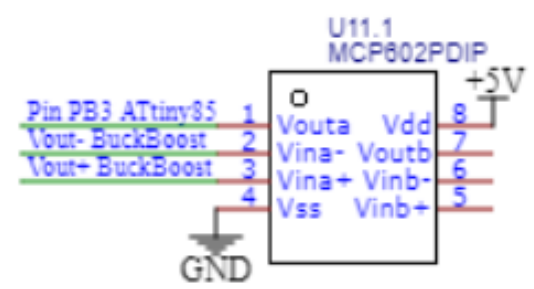

Gambar 3. Rangkaian Sensor Tegangan dengan Op Amps

Journal of Applied Smart Electrical Network and Systems (JASENS) 


\subsection{Perancangan Modul Sensor Arus}

Sensor arus yang digunakan berupa modul sensor arus ACS712 yang memiliki kegunaan untuk mendeteksi besar arus yang mengalir lewat blok terminal. Modul Sensor Arus ACS712 dapat mendeteksi arus hingga 30A dan sinyal arus ini dapat dibaca melalui analog $\mathrm{IO}$ port Arduino.

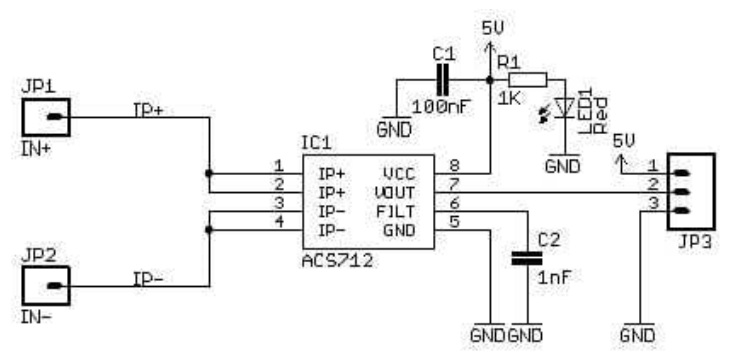

Gambar 4. Diagram pin ACS712

\subsection{Perancangan Buck Boost Converter}

Buck Boost Converter adalah salah satu regulator mode pensaklaran yang menghasilkan tegangan output lebih kecil atau lebih besar daripada tegangan input yang dihasilkan. Pada saat tegangan output dari solarcell lebih dari $14 \mathrm{~V}$ maka buck converter akan bekerja. Pada saat tegangan output solar cell kurang dari $14 \mathrm{~V}$ maka boost converter yang akan bekerja.

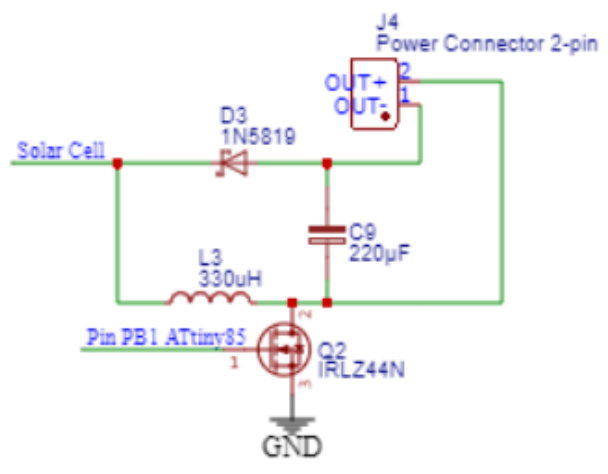

Gambar 5. Rangkaian Sederhana Buck Boost Converter

Perhitungan dari komponen yang digunakan pada rangkaian buck boost converter adalah sebagai berikut:

Vin adalah keluaran tegangan rata-rata dari solar cell

Pmax $\quad=100 \mathrm{Watt}$

$\mathrm{V} \max \quad=22 \mathrm{~V}$

Imax $\quad=4.20 \mathrm{~A}$

Iout rangkaian $=3 \mathrm{~A}$

Fswitching $\quad=30 \mathrm{Khz}$

Duty Cycle merupakan hubungan antara tegangan masukan dan keluaran yang dinyatakan dengan persamaan:

$$
\begin{array}{ll}
\frac{\text { Vo }}{\text { Vin }} & =\frac{D}{1-D} \\
\frac{14}{19} & =\frac{D}{1-D} \\
14(1-D) & =19 D
\end{array}
$$

$\begin{array}{ll}14-14 D & =19 D \\ 14 & =33 D \\ \frac{14}{33} & =D \\ 0.424 & =D\end{array}$

Perhitungan Nilai Induktor

$L=\frac{(1-D)^{2}}{2 . \mathrm{f}} \cdot R$

$L=\frac{(1-0.424)^{2}}{2.30 \mathrm{k}} \cdot 4.66$

$L=\frac{0.332}{60 k} \cdot 4.66$

$L=25.785 u H$

Jadi induktor yang dapat memenuhi perhitungan diatas dan sering di temukan di pasaran bernilai $330 \mathrm{uH}$.

Perhitungan Nilai Kapasitor

$C \equiv \frac{\text { Vo.D }}{\mathrm{R} . \Delta \mathrm{Vo} \cdot \mathrm{f}}$

$$
\begin{aligned}
& C \equiv \frac{14 \cdot 0.424}{4.66 \cdot 0.38 .30} \\
& C \equiv \frac{5.936}{53.124} \\
& C=112 u F
\end{aligned}
$$

Jadi kapasitor yang dapat memenuhi perhitungan diatas dan sering di temukan di pasaran bernilai $220 \mathrm{uF}$.

Pemilihan switch

Switch yang dipakai agar sesuai dengan spesifikasi desain buck boost converter adalah mosfet tipe IRLZ44N karena merupakan mosfet bertipe fast switching, untuk mengaktifkan switchingnya tidak memerlukan tegangan yang besar cukup antara $5 \mathrm{~V}$, dan tidak perlu driver mosfet.

Pemilihan dioda

Dioda yang digunakan pada rangkaian buck boost converter ini adalah 1N5819 Schottky. Spesifikasi dioda 1N5819 Schottky sesuai dengan spesifikasi desain rangkaian buck boost converter yang dipakai. Fitur 1N5819 Schottky sebagai fast switching dioda untuk efesiensi tinggi, cocok untuk arus tinggi, arus reverse yang rendah serta voltage drop yang rendah menjadi dasar pemilihan dioda ini.

\subsection{Perancangan ATtiny85}

Pada rangkaian ini menggambarkan program yang dirancang untuk mikrokontroler ATtiny85.

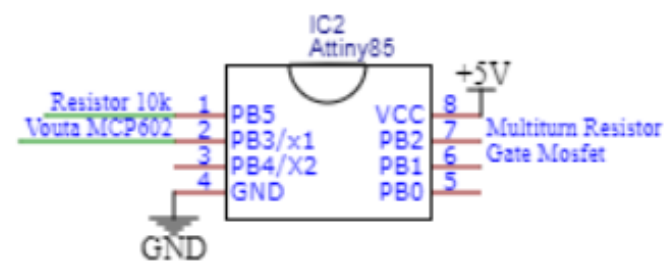

Gambar 6. Rangkaian ATtiny85

Journal of Applied Smart Electrical Network and Systems (JASENS) 
Untuk memprogram ATtiny85 sebagai mikrokontroler \{

dari buck boost converter diperlukan langkah-langkah $\mathrm{pwm}=\mathrm{pwm}-1$;

sebagai berikut :

pwm $=$ constrain $(p w m, 0,254)$;

Upload Arduino ISP pada Arduino Uno.

Buka Arduino $>$ Examples $>$ Arduino ISP $>$ Arduino

ISP.

\}

if (voltage $<$ output)

$\mathrm{pwm}=\mathrm{pwm}+1$

Kemudian upload ke Arduino Uno. Tools $>$ Board $>$ pwm $=$ constrain $($ pwm, 0,254$)$

Arduino Uno.

Kemudian tekan CTRL + U.

Rangkai ATtiny85 dengan Arduino Uno.

Arduino $+5 \mathrm{~V} \quad--->$ ATtiny Pin 8

Arduino Ground ---> ATtiny Pin 4

Arduino Pin 10 ---> ATtiny Pin 1

Arduino Pin 11 ---> ATtiny Pin 5

Arduino Pin 12 ---> ATtiny Pin 6

Arduino Pin 13 ---> ATtiny Pin 7

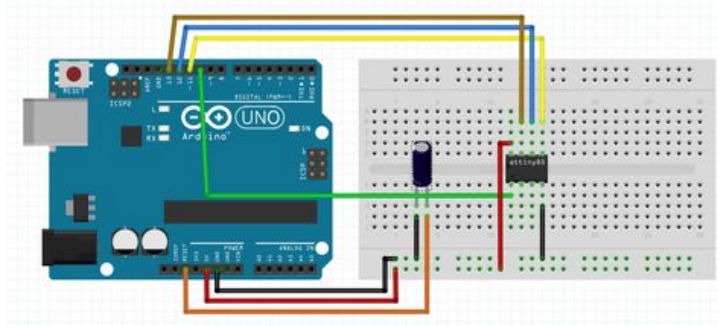

Gambar 7. Wiring ATtiny85 dengan Arduino Uno

Install Board ATtiny pada Arduino.

Listing Program yang digunakan adalah sebagai berikut.

int potentiometer $=\mathrm{A} 1$;

int feedback $=\mathrm{A} 2$;

int $\mathrm{PWM}=1$;

int $\mathrm{pwm}=0$;

void $\operatorname{setup}()\{$

pinMode(potentiometer, INPUT);

pinMode(feedback, INPUT);

pinMode(PWM, OUTPUT);

TCCR0A $=2<<$ COM0A0 $\mid 2<<$ COM0B0 $\mid 3<<$

WGM00;

TCCR0B $=0<<$ WGM02 $\mid 1<<$ CS00;

TCCR $1=0<<$ PWM1A $\mid 0<<$ COM1A0 $\mid 1<<$ CS10;

GTCCR $=1<<$ PWM1B $\mid 2<<$ COM1B0;

\}

void $\operatorname{loop}()$

float voltage $=$ analogRead(potentiometer $)$;

int $\mathrm{pwm}=\operatorname{map}($ voltage $, 0,1024,0,254)$;

float output $=$ analogRead(feedback);

if (voltage $>$ output)

\{

pwm $=$ pwm +1 ;

pwm $=$ constrain $($ pwm, 1, 254);

\}

if (voltage < output)

\{

pwm $=$ pwm- 1

pwm $=$ constrain $(p w m, 1,254)$

\}

if (voltage $>$ output)
\}

analogWrite(PWM,pwm);

\section{Hasil dan Pembahasan}

\subsection{Pengujian Solar Cell}

Pengujian panel surya ini dilakukan agar dapat mengetahui tegangan dan arus yang dihasilkan oleh panel surya dibawah sinar matahari. Pengukuran tegangan dan arus panel surya ini diukur menggunakan multimeter pada waktu yang berbeda-beda. Tabel di bawah merupakan metode pengukuran tegangan dan arus pada panel surya tanpa beban.

Setelah melakukan pengujian tegangan dan arus panel surya, data yang diperoleh dapat ditunjukkan pada tabel 1.

Tabel 1. Pengujian Tegangan dan Arus Solar Cell 100wp

\begin{tabular}{|c|c|c|}
\hline \multirow{2}{*}{ Waktu } & \multicolumn{2}{|c|}{ Tanpa Beban } \\
\cline { 2 - 3 } & $\begin{array}{c}\text { Tegangan } \\
\text { Output }\end{array}$ & $\begin{array}{c}\text { Arus } \\
\text { Output }\end{array}$ \\
\hline $08: 00$ & $19.90 \mathrm{~V}$ & $2,71 \mathrm{~A}$ \\
\hline $08: 30$ & $19.27 \mathrm{~V}$ & $2,45 \mathrm{~A}$ \\
\hline $09: 00$ & $20.40 \mathrm{~V}$ & $3,80 \mathrm{~A}$ \\
\hline $09: 30$ & $20.30 \mathrm{~V}$ & $3,45 \mathrm{~A}$ \\
\hline $10: 00$ & $19.80 \mathrm{~V}$ & $3,09 \mathrm{~A}$ \\
\hline $10: 30$ & $18.90 \mathrm{~V}$ & $2,13 \mathrm{~A}$ \\
\hline $11: 00$ & $19.20 \mathrm{~V}$ & $2,19 \mathrm{~A}$ \\
\hline $11: 30$ & $20.10 \mathrm{~V}$ & $3,24 \mathrm{~A}$ \\
\hline $12: 00$ & $20.50 \mathrm{~V}$ & $3,83 \mathrm{~A}$ \\
\hline $12: 30$ & $20.34 \mathrm{~V}$ & $3,61 \mathrm{~A}$ \\
\hline $13: 00$ & $22.00 \mathrm{~V}$ & $4.20 \mathrm{~A}$ \\
\hline $13: 30$ & $20.90 \mathrm{~V}$ & $3,91 \mathrm{~A}$ \\
\hline $14: 00$ & $20.30 \mathrm{~V}$ & $3,37 \mathrm{~A}$ \\
\hline $14: 30$ & $19.70 \mathrm{~V}$ & $2,85 \mathrm{~A}$ \\
\hline $15: 00$ & $19.40 \mathrm{~V}$ & $1,73 \mathrm{~A}$ \\
\hline $15: 30$ & $19.10 \mathrm{~V}$ & $1,36 \mathrm{~A}$ \\
\hline $16: 00$ & $19.01 \mathrm{~V}$ & $0,63 \mathrm{~A}$ \\
\hline $16: 30$ & $17.56 \mathrm{~V}$ & $0.21 \mathrm{~A}$ \\
\hline $17: 00$ & $7.76 \mathrm{~V}$ & $0,01 \mathrm{~A}$ \\
\hline $17: 30$ & $1.61 \mathrm{~V}$ & $0 \mathrm{~A}$ \\
\hline $18: 00$ & $0 \mathrm{~V}$ & $0 \mathrm{~A}$ \\
\hline
\end{tabular}

Journal of Applied Smart Electrical Network and Systems (JASENS) 
Dari tabel diatas bisa dilihat bahwa dimulai dari jam 3.3. Pengujian Sensor Arus

08.00 sampai dengan jam 16.30 tegangan output pada solar cell diatas $14 \mathrm{~V}$ yang berarti pada kondisi ini tegangan harus diturunkan yaitu dengan buck mode yang didapat dari buck boost converter, yakni menjadi $14 \mathrm{~V}$ sesuai setpoint karena baterai yang mempunyai spesifikasi $12 \mathrm{~V}$. Sedangkan pada saat jam mulai masuk jam 17.00, tegangan output pada solar cell dibawah $14 \mathrm{~V}$ yang berarti pada kondisi ini tegangan perlu dinaikkan yaitu dengan boost mode yang didapat dari buck boost converter. Pada setiap jam, kondisi tegangan dan arus bisa berubah-ubah tergantung pada terik matahari. Pada kondisi matahari yang sangat terik yakni pada jam 13.00, Serial.begin(9600); tegangan output yang dihasilkan pada solar cell \} mencapai 22 V. Sedangkan pada kondisi matahari tidak void loop() \{

terik (sore hari) yakni jam 17.00, tegangan output yang float average $=0$; dihasilkan pada solar cell hanya $7.76 \mathrm{~V}$.

\subsection{Pengujian Sensor Tegangan}

Pembagi tegangan digunakan untuk mengetahui nilai \} tegangan di suatu titik, dimana pada rangkaian pembagi Serial.print("Current :"); tegangan ini digunakan 2 buah resistor yang dirangkai Serial.print(average/1000); secara seri. Tujuan dari pengujian pembagi tegangan ini Serial.println("A"); adalah untuk mengetahui apakah hasil Vout maksimum $\}$ yang dihasilkan mencapai $5 \mathrm{~V}$, karena tegangan yang dapat diolah oleh ADC mikrokontroller adalah sebesar 5V. Setelah melakukan pengujian pada sensor tegangan, data yang diperoleh dapat ditunjukkan pada tabel 2. Dari tabel 2 bisa disimpulkan bahwa hasil perhitungan (V out teori) tidak pasti sama dengan hasil dari pengukuran menggunakan avometer ( $\mathrm{V}$ out praktek) karena didapatkan perbedaan hasil perhitungan dan hasil pengukuran dengan error nilai terkecilnya adalah $0 \%$ dan error dengan nilai terbesarnya adalah $1.13 \%$ pada saat tegangan $22 \mathrm{~V}$. Bisa disimpulkan disini bahwa error bisa terjadi kapan saja dan juga bisa tidak terjadi dengan melihat nilai dari nomor 4 ke 5 , dan 5 ke 6 .

Tabel 2. Pengujian Sensor Tegangan

\begin{tabular}{|c|c|c|c|c|c|}
\hline No & $\begin{array}{c}\mathrm{V} \\
\text { Input }\end{array}$ & $\begin{array}{c}\mathrm{V} \text { Out } \\
\text { Praktek }\end{array}$ & $\begin{array}{c}\mathrm{V} \\
\text { out } \\
\text { Teori }\end{array}$ & Error & $\begin{array}{c}\text { Error } \\
(\%)\end{array}$ \\
\hline 1 & 0 & 0 & 0 & 0 & $0.00 \%$ \\
\hline 2 & 4 & 0.80 & 0.80 & 0 & $0.00 \%$ \\
\hline 3 & 8 & 1.59 & 1.60 & 0.00625 & $0.63 \%$ \\
\hline 4 & 12 & 2.39 & 2.40 & 0.00416 & $0.42 \%$ \\
\hline 5 & 16 & 3.20 & 3.20 & 0 & $0.00 \%$ \\
\hline 6 & 20 & 4.12 & 4 & 0.03 & $0.3 \%$ \\
\hline 7 & 22 & 4.45 & 4.40 & 0.0113 & $1.13 \%$ \\
\hline
\end{tabular}

Journal of Applied Smart Electrical Network and Systems (JASENS)
Setelah melakukan pengujian pada sensor arus, data yang diperoleh dapat ditunjukkan pada tabel 3.

Tabel 3. Pengujian Sensor Arus

\begin{tabular}{|c|c|c|c|c|}
\hline No & $\begin{array}{c}\text { I Out } \\
\text { Praktek }\end{array}$ & $\begin{array}{c}\text { I Out } \\
\text { Terbaca }\end{array}$ & Error & $\begin{array}{c}\text { Error } \\
(\%)\end{array}$ \\
\hline 1 & 0.10 & 0.10 & 0 & $0 \%$ \\
\hline 2 & 0.30 & 0.30 & 0 & $0 \%$ \\
\hline 3 & 0.50 & 0.50 & 0 & $0 \%$ \\
\hline 4 & 0.70 & 0.72 & 0.028 & $2.8 \%$ \\
\hline 5 & 0.90 & 0.92 & 0.022 & $2.2 \%$ \\
\hline 6 & 1.10 & 1.12 & 0.018 & $1.8 \%$ \\
\hline 7 & 1.30 & 1.32 & 0.015 & $1.5 \%$ \\
\hline 8 & 1.45 & 1.46 & 0.006 & $0.6 \%$ \\
\hline
\end{tabular}

Dari tabel diatas bisa ditarik kesimpulan bahwa hasil pengukuran menggunakan avometer dan hasil pengujian sensor arus menggunakan program ada sebuah error. Pada nomer 1,2, dan 3 dengan arus kecil masih belum ada error, tetapi saat memasuki nomer 4 dengan arus yang sudah mulai besar, baru menemukan error. Masuk ke nomer 5 dan seterusnya error semakin kecil.

\subsection{Pengujian Buck Boost Converter}

Pengujian ini dilakukan agar dapat mengetahui output yang dihasilkan oleh buck boost converter, bentuk sinyal PWM serta frekuensi sinyal PWM yang dihasilkan dari mikrokontroler. Pengujian dilakukan dengan cara melihat sinyal yang dihasilkan dari mikrokontroler menggunakan osciloscope. Dengan menggunakan osciloscope maka sinyal dapat dilihat bentuk, frekuensi dan juga tegangan sinyal yang 
dihasilkan. Bentuk sinyal PWM dapat dilihat dengan ketika duty cycle diubah persentasenya serta tidak cara mengganti nilai duty cycle. terlihat adanya noise ketika dilihat di osciloscope. Dengan ini dapat disimpulkan bahwa sinyal PWM yang

Setelah melakukan pengujian pada sensor tegangan, data yang diperoleh dapat ditunjukkan pada tabel 4.
Tabel 4. Pengujian Buck Boost Converter

\begin{tabular}{|c|c|c|c|}
\hline No. & $\begin{array}{c}\text { Tegangan } \\
\text { Input }\end{array}$ & $\begin{array}{c}\text { Duty } \\
\text { Cycle }\end{array}$ & Tegangan Output \\
\hline 1 & $19 \mathrm{~V}$ & $10 \%$ & $2.1 \mathrm{~V}$ \\
\hline 2 & $19 \mathrm{~V}$ & $20 \%$ & $4.75 \mathrm{~V}$ \\
\hline 3 & $19 \mathrm{~V}$ & $30 \%$ & $8.14 \mathrm{~V}$ \\
\hline 4 & $19 \mathrm{~V}$ & $40 \%$ & $12.66 \mathrm{~V}$ \\
\hline 5 & $19 \mathrm{~V}$ & $50 \%$ & $19 \mathrm{~V}$ \\
\hline 6 & $19 \mathrm{~V}$ & $60 \%$ & $28.5 \mathrm{~V}$ \\
\hline 7 & $19 \mathrm{~V}$ & $70 \%$ & $44.33 \mathrm{~V}$ \\
\hline 8 & $19 \mathrm{~V}$ & $80 \%$ & $76 \mathrm{~V}$ \\
\hline 9 & $19 \mathrm{~V}$ & $90 \%$ & $171 \mathrm{~V}$ \\
\hline
\end{tabular}

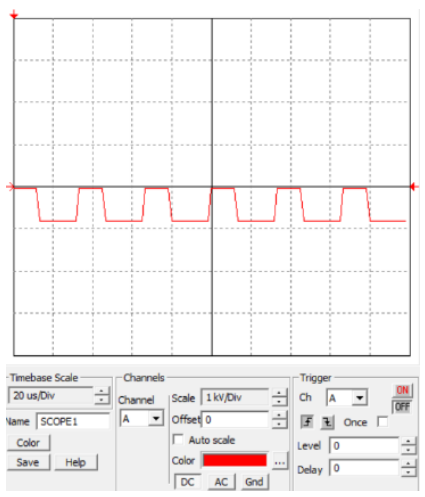

Gambar 8. Bentuk Sinyal Saat Duty Cycle 10\%

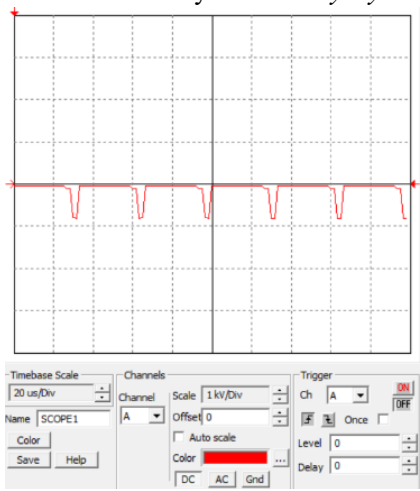

Gambar 9. Bentuk Sinyal Saat Duty Cycle 80\% dihasilkan dapat dipakai sebagai masukan mosfet untuk melakukan proses switching.

\subsection{Pengujian Converter untuk Charging Baterai}

Tujuan dilakukan pengujian converter untuk charging baterai ini adalah untuk mengetahui apakah buck boost converter sudah bisa dilakukan untuk pengisian baterai. Peralatan yang diperlukan pada pengujian ini yaitu solar cell, rangkaian buck boost converter dengan beban yang digunakan adalah battery $12 \mathrm{~V} / 5 \mathrm{Ah}$.

Setelah melakukan pengujian charging baterai, data yang diperoleh dapat ditunjukkan pada tabel 5.

Tabel 5. Pengujian Converter Untuk Charging Baterai

\begin{tabular}{|c|c|c|c|c|c|}
\hline Jam & $\begin{array}{c}\text { Arah } \\
\text { Matahari } \\
\text { terhadap } \\
\text { Solar Cell }\end{array}$ & $\begin{array}{c}\text { Tegangan } \\
\text { Input }\end{array}$ & $\begin{array}{c}\text { Duty } \\
\text { Cycle }\end{array}$ & $\begin{array}{c}\text { Tegangan } \\
\text { Output }\end{array}$ & $\begin{array}{c}\text { Arus } \\
\text { Output }\end{array}$ \\
\hline 12.00 & $120^{\circ}$ & $20.3 \mathrm{~V}$ & $40.9 \%$ & $14,06 \mathrm{~V}$ & $1,82 \mathrm{~A}$ \\
\hline 12.30 & $115^{\circ}$ & $20.5 \mathrm{~V}$ & $40.8 \%$ & $14,16 \mathrm{~V}$ & $1,60 \mathrm{~A}$ \\
\hline 13.00 & $110^{\circ}$ & $22 \mathrm{~V}$ & $39.3 \%$ & $14,27 \mathrm{~V}$ & $1.19 \mathrm{~A}$ \\
\hline 13.30 & $105^{\circ}$ & $20.9 \mathrm{~V}$ & $40.4 \%$ & $14,20 \mathrm{~V}$ & $0,90 \mathrm{~A}$ \\
\hline 14.00 & $100^{\circ}$ & $20.2 \mathrm{~V}$ & $41 \%$ & $14,04 \mathrm{~V}$ & $0,66 \mathrm{~A}$ \\
\hline 14.30 & $90^{\circ}$ & $20.1 \mathrm{~V}$ & $41.1 \%$ & $14,03 \mathrm{~V}$ & $0,30 \mathrm{~A}$ \\
\hline 15.00 & $75^{\circ}$ & $20 \mathrm{~V}$ & $41.1 \%$ & $14,01 \mathrm{~V}$ & $0,06 \mathrm{~A}$ \\
\hline 15.30 & $60^{\circ}$ & $19.1 \mathrm{~V}$ & $42.2 \%$ & $14,00 \mathrm{~V}$ & $0 \mathrm{~A}$ \\
\hline
\end{tabular}

Setelah melakukan pengujian charging battery dengan arah awal solar cell yang menghadap ke arah barat $\left(120^{\circ}\right.$ terhadap sinar matahari) pada saat waktu terik matahari sesuai data di pengujian solar cell yakni jam 12.00 sampai jam 15.30, diperoleh data bahwa converter sudah dapat melakukan pengisian battery dalam waktu \pm 4 jam dengan optimal dimana output tegangan stabil diangka $14 \mathrm{~V}$ dengan tegangan input awal sebesar $20.3 \mathrm{~V}$ dan arus output awal sebesar 1,82 A dengan rata-rata duty cycle yang dihasilkan oleh mikrokontroler sebesar $40 \%$.

\section{Kesimpulan}

Setelah melakukan pengujian, didapatkan hasil seperti Berdasarkan hasil pengujian, penggunaan rangkaian tabel diatas bahwa saat duty cycle dibawah 50\%, maka buck boost converter dengan menggunakan komponen output tegangan yang dihasilkan akan lebih kecil dari fast switching sangat berpengaruh terhadap battery tegangan input. Sebaliknya, saat duty cycle diatas 50\% charging. Dengan menggunakan AKI 5AH kondisi maka output tegangan yang dihasilkan akan lebih besar kosong dapat mencharging hinga penuh dalam waktu \pm 4 dari tagangan input. Semakin kecil duty cycle yang jam dengan kondisi arus charging awal sebesar 1.82 A, dihasilkan oleh mikrokontroler, maka output tegangan dengan daya dari buck boost converter yang terserap yang dihasilkan juga kecil. Sebaliknya, jika duty cycle sebesar 25.6 watt $(14.06 \mathrm{~V}, 1.82 \mathrm{~A})$.

yang dihasilkan oleh mikrokontroler besar, maka output tegangan juga akan besar. Sinyal PWM yang dihasilkan Daftar Rujukan

oleh mikrokontroler sudah sesuai dengan spesifikasi alat. Sinyal PWM yang dihasilkan juga sudah sesuai

1] Dany, Rizka., 2012. Rancang Bangun Kontroler Baterai Charger Untuk Solar Cell . Tugas Akhir, D3 Teknik Elektro, Surabaya. 
[2] Aulia Rizki., 2012 " Battery Charger Dengan Converter Boost ", Tugas Akhir, PENS, Surabaya.

[3] Tjok Gd. Visnu Semara Putra. 2015. Analisa Unjuk Kerja Pembangkit Listrik Tenaga Surya 15 KW Di Dusun Asah Teben Desa Datah Karangasem. (Bachelor thesis). Bali: Universitas Udayana.

[4] R. Salman., 2013 .Analisis Perencanaan Penggunaan Sistem Pembangkit Listrik Tenaga Surya (SOLAR PV) Untuk Perumahan (Solar Home System). Majalah Ilmiah Bina Teknik, vol. 1(1), pp. 46-51.

[5] A. Najmurrokhman dan M. Fajrin., 2010. Prototipe Penjejak Cahaya Matahari untuk Mempertinggi Efisiensi Penyerapan Energi Matahari pada Solar Cell, Prosiding Seminar Nasional Energi, Jurusan Fisika Unpad, 3 November 2010 hlm.145 - 150.

[6] M. R. I. Sarker, Md. Riaz Pervez, and R.A Beg., 2010. Design, Fabrication and Experimental Study of a Novel Two-Axis Sun Tracke. International Journal of Mechanical \& Mechatronics Engineering IJMME-IJENS Vol. 10 No. 01, ISSN: 2077-124X, February 2010, pp. $13-18$.

[7] J. H. Karp, E. J. Tremblay, and J. E. Ford., 2010. Planar microoptic solar concentrator, Optics Express, Vol. 18, Issue 2, 2010, pp. 1122-1133.

[8] R. H. Y. Perdana and F. Fibriana, "An intelligent switch with back-propagation neural network based hybrid power system," in Journal of Physics: Conference Series, 2018, vol. 983, no. 1.

[9] T. T. N. Khatib, A. Mohamed, R.J. Khan and N. Amin., 2009. A novel active sun tracking controller for photovoltaic panels. J. Applied Sci., 9, 2009, pp. 4050 - 4055.

[10]X. Xiaoli dan Q. Daoe., 2011. Remote Monitoring and Control of Photovoltaic System Using Wireless Sensor Network. International Conference on Electric Information and Control Engineering (ICEICE), Wuhan, China, 15-17 April 2011, pp. 633638.

[11]E. Roman, E., et al., 2006. Intelligent PV Module for Gridconnected PV Systems. IEEE Trans. on Industrial Electronics, vol. 53, no. 4, April 2006, pp. 1066-1073. 